\title{
The Professional Ecstatic in His Social and Ritual Position
}

\author{
By BIRGITTE SONNE
}

The title of this paper will need some elucidation below. Its aim is to delimit the social status of the professional ecstatic, by means of a series of mostly sociological criteria. These, then, are tested on historical material, the sources of the traditional cultures of the Eskimos.

\section{Definitions}

The professional ecstatic is according to my definition: a religious specialist, who has become recognized as a person able to carry out an ecstatic ritual, corresponding with the local cultural expectations in force. The ecstatic ritual per se comprises a number of persons, i.e. it is a collective ritual. It consists of a regular sequence of acts entailing the entry of the recognized specialist, the professional ecstatic, into one of the dissociated psychic states under the common denomination of ecstasy (II shall not go into the physio-psychology of these states and their attending perceptions). A possible effect of the collective ecstatic ritual is that the other participants also enter into a state of ecstasy, but by definition only the professional himself is required to do so. Thus the definition does not cover ecstatic rituals intended to induce all participants, by turns or simultaneously, to enter a state of ecstasy. Obversely, the definition requires that in the culture or subculture referred to, the ecstasy is ascribed a religious content irrespective of the forms of this content. Thus it is irrelevant whether the culture or subculture in question interprets the ecstasy as possession by a super-natural being, or gives it any other religious content. ${ }^{1}$

Part of the criteria that may be employed as a measure of the professional ecstatic's social status, is covered by the determining designation, social

\footnotetext{
1 E. Bourguignon (1973) analyzes data in Murdock's Ethnographic Atlas to arrive inter alia at this result: on statistical probability, the degree of complexity in a society will determine the type of interpretation that society will prefer, whether possession and/or other types of phenomena. Murdock's data have been criticized, so Bourguignon's result
}

may be questioned. Yet, Siikala's more detailed analysis of written sources for Siberian shamans also points to the fact that the preferred type of interpretation varies with social factors (1978, conclusions). If the preferred interpretation is thus a dependent variable, its influence on the professional ecstatic's status cannot be independent. 
and cultic position. The explanation of these two terms will follow in reversed order.

By the ritual position of the professional ecstatic I denote his ritual place in the entire ritual pattern of his society. Or put more distinctly: what ecstatic ritual duties does he have, and how large a part in the whole range of collective rituals within his society will his duties comprise? The latter question is rarely raised in specialist literature, but the answer may give an indication of the status of the professional ecstatic, as I shall demonstrate towards the end of this paper.

The social position of a professional ecstatic can profitably be regarded as a position in society that he has come to obtain. Previous to his recognition as an ecstatic specialist he has one social position, and after being recognized presumably another. The social position thus acquired can be measured by many possible criteria, but I shall concentrate on the following: the economic conditions of recognition; its inherent possibilities, partly for control of social morals, partly for influence on political and juridical decisions, in the society in question.

The delimitations of social position by these criteria depend, in certain types of society, on the social radius employed as a yardstick. The traditional Eskimo societies were relatively small autonomous entities, with a simple division of labour, a relatively loose social structure and with a varying but never very complicated political organization. (The complexity of political organization is measured by the existence or non-existence of juridical institutions on a local or higher level, and of a leadership structure with institutionalized rights in an inherited or non-inheritable succession.) In these and in corresponding societies the social position of the professional ecstatic can be simply gauged with reference to society in its entirety, because the entire autonomous society is his field of action. In larger and considerably more complex societies, on the other hand, his field of activity does not comprise society to its full extent, that is, society as a political entity. This is only the case if through his ecstatic ritual practice he has the possibility of exerting influence upon decisions taken at the highest level of juridical and political authority. But if he does not have these possibilities of influence, his active field is restricted to a subgroup within his complex society. Here his social position can be measured on two different social radii: one including the subgroup, and another embracing the entire society. In contemporary large modern states, the professional ecstatic acts for the lower or intermediate social strata; while in the smaller autonomous kingdoms or chieftaincies of the past, he could rise to influence in high places, if recognition allowed this possibility. Indeed, he could do so,-for these autonomous and relatively complex societies are coming to be a thing of the 
past. International market economy and political hegemony reach deep into decision-making processes in most societies to-day. And so the question arises of social change in relation to ecstatic religion. Analysis and delimitation of a professional ecstatic's social position is simpler in relatively stable societies, than in societies undergoing continuous and dramatic changes. Sometimes the ecstatic's potential for influence will increase, sometimes decrease, and at times new cults will arise around fresh ecstatic specialists; all this because the social and economic bases for his recognition change. But I shall not enter into the methodological problems arising when social change complicates the analysis of the professonal ecstatic's social position. My subject is his social and ritual position among the Eskimos in their traditional, and thus relatively stable, societal cultures. Here the criteria are social order and the ritual patterns of the various societies in their entirety. As professional ecstatics among the Eskimos may be defined as shamans, I shall henceforth call them so.

\section{A note on Eskimo culture}

The Eskimos have their habitat around the polar circle from Siberia to Greenland, from the North-Easternmost point of Asia, on the islands of the Bering Strait and the Bering Sea, along the coastal line of the North American continent, from the coast of Alaska turning South towards the Pacific, and in the arc up to the Hamilton Inlet on the Eastern coast of Labrador (Newfoundland) and across to Greenland and on to its SouthEastern coast.

Hunting and fishing formed the basis of subsistence for all Eskimos. Most groups $^{2}$ would hunt both sea animals from the coast, and land animals in the interior. A few groups, the inland Eskimos, only hunted and fished in the interior, whilst a single group, the Polar Eskimos in North Greenland, only exploited the resources of the sea.-The annual cycle of all Eskimos fell into two, sometimes more, periods: a sedentary, and a more or less nomadic period. During the sedentary period several families would live together in societies proper, which during the second period would dissolve into smaller family groups. In districts with permanent habitation, as for example among the Pacific Eskimos, single families would go on longer trips during this period; while most other Eskimos, the semi-sedentary, would spend their whole nomadic period moving from place to place. The duration of the sedentary period, in relation to the more or less nomadic one, would vary considerably from one Eskimo group to another. These

\footnotetext{
2 "Group" designates each sector of Eskimos who spoke a common dialect and hunted within a delimited territory.
} 
relative variations depended on the quantity and character of local resources, and the extent to which they were exploited. Thus the sedentary period was longer among the coastal Eskimos, hunting large marine animals in spring and early summer (e.g. Baffinlanders and Iglulik), than among those hunting seal at breathing holes in settled communities on sea ice in winter only, and which dispersed into families to hunt along the shores and in the inland in spring and summer (Netsilik and Copper).-The same ecological variations seem to have been the decisive factor behind the rich variations in types of society characterizing the Eskimo territories as a whole. The Polar Eskimos would live in small, labile and preponderantly nomadic societies, and were informally led by mature, experienced hunters. In contrast, the Pacific Eskimos were divided into very large, relatively stable, and preponderantly sedentary societies; they carried on collective hunts for big marine animals, and went to war under the leadership of single persons, who had taken over their leadership status from a father, uncle or elder brother.-Between these two extremes, all other Eskimo societies represented every conceivable intermediate form. It is thus in fairly different societies that the social positions of Eskimo shamans must be measured.

\section{The economic background of Eskimo shamans}

Apart from a single possible exception, any Eskimo male or female could train himself to be a shaman. In addition, an Eskimo shaman was paid for his individual performances. But even if these payments might be a welcome incidental surplus for shamans of low economic status, no shaman could make a living on these alone. In other words, the shamans were only part-time specialists among the Eskimos. In everyday life the male shamans had the same occupations as other men in the division of labour, and the female ones the same as other women. Individual shamans would lead a normal family life like all other persons-sons, daughters, fathers or mothers.

But since most Eskimos were men, I shall here cite them in the masculine gender. It should be stressed, though, that male shamans would not necessarily have any greater shaman gifts or powers than female ones.

The possible exception may be the shamans on Kodiak in the Pacific. According to a unique and unverifiable source (Black 1977), the Kodiak shamans were born as boys, educated like women, and remained unmarried. They were destined for the task of shaman from their birth, and therefore evidently prevented from exploiting the outlets for prestige which were open to ordinary men and women. These unmarried shamans had a special status, and they were presumably members of well-to-do families, 
where their position was that of servingmaid. All other Eskimo shamans, like any man or woman, could exploit the given possibilities for obtaining prestige, dependent on the individual's family situation and his or her exertions as a hunter or in the household.-I shall currently denote the shaman's varying positions on this scale of prestige as his Economic Status.

To summarise: no Eskimo shaman could live from his shaman activities. He was paid for each performance, but although this profit would be a welcome surplus for shamans of low economic status, it could never afford him a living. So the shaman was a part-time specialist, and the primary basis of his economy rested on his economic status.

\section{Siikala's Siberian shaman typology}

The economic conditions of Eskimo shamans correspond to those prevailing for shamans among Chukchee and Koryaks in North-Eastern Siberia. Anna-Leena Siikala (1978) has established a typology for the Siberian shamans and places Chukchee and Koryak shamans within the type she calls The Professional Shaman. Her meaning differs slightly from my sense of the word professional by denoting that the shaman receives payment for each of his shamanistic performances. Siikala further characterizes this type of Professional as follows: the shaman is not bound to any definite group of people; on the contrary, he can shamanize for anybody. He does not obtain his recognition through a separate ritual of initiation, and he has no ritual duties in the collective economic rituals of his society.

As stated, the Eskimo shamans apparently tally with this type, because they were paid for their separate performances. Furthermore they could shamanize for anybody. But here the similarities end (apart from the shamans of a unique eskimo group, the Taremiuts at Point Barrow, who fulfill all of the criteria for Siikala's Professional Shaman). For all other Eskimo shamans the following points obtain: they did have ritual tasks in the economic rituals of their society, and most of them had to pass a special ritual of initiation to obtain recognition as a shaman. In this point they resemble the shamans in Siikala's additional three types: the Small Group shaman; the Clan shaman; and the Professional Regional shaman. But as the Eskimo shamans, as noted, could shamanize for anybody, they do not tally with any of these three shaman types. For they were bound to shamanize respectively for the small group or the clan whose members they were, and within the limited geographical area in which they had obtained their recognition enabling them to shamanize.

In short: the Eskimo shamans cannot be placed within Siikala's Siberian typology.

One certain exception is provided by the above shamans at Point Barrow 
(Spencer 1959, $303 \mathrm{f}$ ); while a single fact about a group of Inland Eskimos in North Alaska, Nunamiut, points to their having maintained small-group shamans at some time in the past (ibid., 314). This serves to emphasize that Siikala's typology, which is fully applicable to Siberian shamans, cannot be simply transferred to Eskimo ones. And yet, of Siikala's typological criteria, the economic one and the one about the shaman's duties in collective rituals can be profitably applied for delimiting the personal, social status of Eskimo shamans. The economic criterium I treated above; but the question of shamans' ritual duties must be treated in depth, when I have elucidated their possibilities of political and juridical influence.

\section{The shaman's possibilities of influence}

The question of the shaman's possibilities of influence on social morality and on decisions concerning the collective, requires an extended and more differentiated answer.

In his 'Ecstatic Religion' (1971) with its cross-cultural analyses of ecstatic cults, Ioan Lewis places the professional ecstatic's possible influence in three fields: control of social morality; influence on decisions of courts on a local or higher level; and influence on the succession of political leaders.

Lewis preferably selects his instances from East Africa, but one example is taken from Eskimo shamans. This analysis leads to far-reaching conclusions and must definitely be characterised as a daring venture, since Lewis obtains his whole knowledge of Eskimos from only one book (Rasmussen 1929) and two papers (Balikci 1963 and Murphy 1964). As this literature concerns only one Bering Strait and two Central (Canadian) Eskimo groups (Iglulingmiut, Nestilingmiut and St. Lawrence Islanders), Lewis has been hard put to discover the wide relative differences in Eskimo societal conditions that I mentioned above. But in addition Lewis selects his information from the two books so as to correspond with his theoretical considerations. Lewis's extensive theory about ecstatic cults is built on a typology, whose differentiating criterium is the relation of the cult to the collective morality of the society in question. Of the three types that Lewis establishes in this way, I shall deal with only one, the Central Cult type, because Lewis uses the Eskimo shaman rituals as one instance of this type. ${ }^{3}$

The Central Cult is characterized by its intimate connection with the collective morality of society, because its ecstatic specialist exerts a decisive control on this morality in his cult practises. In the societal envelopment of the central cult, crisis situations are interpreted as the negative

\footnotetext{
${ }^{3}$ My treatment involves some criticism of Lewis' Central cult type. For criticisms of his second type, the Peripheral Cylt, see Bour-

guignon 1973; Douglas 1975; Sibisi 1975; Swantz 1976.
} 
reactions of forefathers or nature spirits to social conflicts and infringements of morality, and the culprits are pointed out by the professional ecstatic through the cult rituals.

Lewis further states that in societies with a certain degree of political organization, the central-cultic specialist shares his moral control with the political leaders and judges; while in societies without a political organization proper, he has complete control within his own hands.

I. The Eskimo shaman's control of social morality. Among the latter societies the Eskimo ones are numbered, notes Lewis. They have no juridical institutions, and as their informal leaders have no juridical authority, the shaman must exercise a considerable control of social morality. Furthermore, the shaman can here function simultaneously as informal leader, which is an impossible combination in societies with some degree of political organization.

II. The Eskimos' means of social control. In his description of the Eskimos, Lewis is exclusively concerned with the shaman's possible control of social morality, the only possibility left that Lewis can see, because he finds no juridical institutions among the Eskimos. And there were none. But other means of social control existed, of which a couple are described in the literature from which Lewis takes his information.

The strongest social control was executed by public opinion, which is extremely effective in groups of the manageable size that characterized Eskimo society. Besides, the Eskimos had even more institutions functioning as the long arm of opinion, viz.: the song contest; the joking partnership; the song-and song-dance festivals.-In the song contest and the joking partnership (Hoebel 1967; Lantis 1946 with references; Kleivan 1971) two persons would alternately deride each other to the delight of the public. Resounding acclamation arose if the derision fully corresponded to public opinion; but enthusiasm waned if insults were below or above a justified level. The song-and the song-dance-festivals served the accepted and appreciated self-praise of single individuals. They depicted their own and/or their near forefathers' outstanding experiences and deeds in songs that left no listener in doubt as to the moral value of these weighty events (Sonne 1978). All these institutions exercising control and even an exemplary effect on morality, was outside the domains of the shaman.

\section{"Juridical" decisions}

The song contest channeled some part of dyadic conflicts, because the rules of this institution prevented conflicting parties from coming to blows. ${ }^{4}$ On

\footnotetext{
${ }^{4}$ Underlined by Kleivan 1971 for the Western Greenlanders in particular.
} 
the other hand, the Eskimos did not demand that two persons who had fallen into serious disagreement laid their conflict open to public 'judgement' in a song contest. Their difference was a private affair, which did not necessarily involve other parties than the conflicting persons, and possibly their close relatives. Dyadic conflicts did not become public affairs, unless one person developed into a habitual criminal and so posed a threat to economic cooperation within the society. In that case, a more or less formal deliberation was held about the criminal's possible extermination, exile, isolation or reproof. ${ }^{5}$ During the deliberation people would listen most to the honoured, mature and aged men, and to their primus inter pares, the informal leader, who as a rule had the decisive word. But his 'judgement' had to correspond with the consensus he could infer from pronouncements of the honoured, mature men. No more in such deliberations was the shaman's professional assistance required. He would take part as an ordinary person, on a par with other men, whose weight of opinion depended on their economic status. ${ }^{6}$

The ways in which the Eskimo shaman executed his main social control nevertheless causes Lewis certain problems. Contrary to other societies with central cults which serve as examples for Lewis, the Eskimos did not interpret a crisis situation as the result of some transgression of social morality. The most frequent cause was seen in infringements of taboos, i.e. the breaking of rules in force for relations with surrounding nature. Thus any direct control of morals could hardly be the effect of shaman rituals in crisis situations, a fact which Lewis does admit. But he continues: as most infringements of taboo can cause a common crisis situation, such transgressions must be synonymous with infringements of morality; and, as the Eskimo shaman controls the execution of taboo rules, he would by this leverage execute an important indirect control on social morals.

I should like to make the following comment on Lewis:

It is questionable whether the Eskimo shaman exerted any wider control on social morality because of his control of taboo rules, which was his acknowledged area of authority. Taboo rules were numerous, and where they were most numerous, infringements of taboo were inevitable. The Eskimos did not react with strong negative sanctions against grown-ups, who might from time to time break a taboo. Only the extremely few persons

\footnotetext{
5 In some groups of small societies, the culprit's close kin made the decision and did away with their relative themselves (Steenhoven 1962).

${ }^{6}$ Bilby 1923 offers a single case from the
}

Eastern Baffinlanders where the shamans, probably irrespective of economic status, had a greater influence on such "juridical" procedures than was the case among the other Eskimos. 
who time and again seriously broke taboos, leading to a serious common crisis situation, had to be reprimanded with a reminder. ${ }^{7}$

In his argument Lewis chiefly stresses one collective ritual led by the shaman, which I might dub 'the public confession'. It was a widespread ritual in the larger part of the Eskimo world, for neutralizing a common serious situation of crisis. All grown-up members of society took part and in turn confessed all the breaks of taboo, of which they had recently been guilty. The shaman who presided at the public confession had the task of pointing out the special break of taboo which, according to his special knowledge, must be the cause of common misery. As a rule, this break of taboo was the last one disclosed in a long series of confidences; and when the shaman declared himself satisfied, relief would spread among the participants. As the very disclosure would neutralize the ominous effects of the many breaks of taboo, a public confession removed all imaginable causes of the critical situation. The ritual did not serve to point out a guilty person for chastisement. The participant who had confessed the infringement of taboo which, according to opinion and the shaman's assessment, was the proper cause of the crisis, neither incurred any odium or was made the object of other negative social sanctions.

The prevalent mood when the ritual was ended was relief. And it is my view that the public confession served primarily as a therapeutic ritual for reducing the anxiety, which a serious situation of crisis would produce among all members of society. Or stated theoretically: the shaman exerted a minimal indirect control on morals in his function as the guardian of taboo rules.

\section{Status as shaman and leader}

The Eskimo shaman could attain leader status, says Lewis. To be sure, this was a theoretical possibility in most Eskimo societies; but a shaman never became a leader due to his shaman powers in isolation. A leader's qualities were not identical with a shaman's powers. A leader was always a reliable person, an outstanding provider, an experienced adviser in hunting affairs, and besides, he was generous with the surplus resulting from his excellent providing capacity. In societies where hunting demanded organized cooperation under a single man's leadership, he should also have organisatorial gifts. If a shaman, apart from his recognized shaman powers, possessed

\footnotetext{
${ }^{7}$ This statement is based on my extensive reading in Eskimo literature. It is sustained by van den Steenhoven's conclusion on the topic (1962), based on a detailed analysis of written sources and personal field notes from
}

Caribou and Netsilik Eskimos. The latter group had one of the most comprehensive and restrictive taboo networks in all the Eskimo territories. 
these qualities, he could attain a leader's status. His advice as a shaman, in common situations of crisis, combined with his authority as a leader, would endow him with particularly great authority.

As stated, the combination of leader and shaman status in the same person was a theoretical possibility in the majority of Eskimo societies. In practice it was another matter. I shall return shortly to this point. But before that, one question must be answered: suppose the Eskimo shaman was not one of the honoured, mature men, nor their informal leader with high economic status; would he then have any appreciable part in social control? The reply is, yes.

\section{The shaman as witch-finder}

Premature deaths, illnesses, and common situations of crisis, which could not be explained by breaches of taboo, were interpreted as the effects of witchcraft. According to Lewis, the accusations of witcheraft would always be raised against a shaman from outgroup societies.-My comment here is that this was often the case, although it was far from being an invariable rule. Such accusations might be directed against both ordinary people and shamans, in other societies and in one's own. Possible witchcraft accusations were always a favourite subject of conversation behind closed doors; but the shaman could raise such accusations in public during a séance. Only he then had to be certain of support; for if he accused a person enjoying widespread confidence and/or respect, the shaman could fall foul of public opinion, with the effect that suspicion would turn against his own person. In his function of witch-hunter, the shaman in other words exercized a certain control but, at the same time, he was in this capacity himself under social control.

Because of his special powers, which he could use to the harm or to the advantage of others, the Eskimo shaman, like his colleagues all over the world, fell an easy prey to suspicion and accusations of witchcraft. Thus there arose the ambivalent attitude toward the shaman which was conspicuous in all Eskimo territories. The attitude contained a mixture of respect and fear, which might be combined with confidence, if the shaman had high economic status, and at the same time was reliable and sociable in behaviour. In the contrary case, that is: when his economic status was low; if his diagnoses often went against the consensus; and if his prognostications, too, often failed, he was classed with habitual criminals, the treatment of whom has been described above. Yet it was always a risky affair to attack a shaman, because his spiritual means of defence were numerous and efficient. Murders of unpopular shamans did nonetheless occur at intervals.

This ambivalent attitude to the shaman was, as noted, pronounced in all 
Eskimo societies. In itself, recognition of the shaman gave him no clearly delimited and riskfree social position. The shaman's tasks constituted no office. They gave him limited economic advantages, and a limited influen:se on social control. Only by virtue of high economic status together with sociable qualities could the Eskimo shaman support his prestige, which was measured by the extent of his shaman powers. If he lacked these qualities, the fear that his shaman prestige engendered could break out in a joint decision leading to his isolation, exile or even extermination.

With this risk in mind the question then arises: what advantages would the shaman's duties confer among the Eskimos? In my opinion, the answer is to be found in the special prestige that shaman powers would confer, in spite of the accompanying drawbacks. They increased the shaman's personal security in all dyadic conflicts in which he and any other individuals might become entangled. ${ }^{8}$ As formerly mentioned these dyadic conflicts, which would include the claim of blood revenge, were private affairs which the parties involved had to tackle themselves. In such conflicts, too, the low-status shaman was better situated with his spiritual means of defence ${ }^{9}$ than were ordinary persons of any status. The shaman's powers would thus afford increased personal security but, as has been emphasized, only up to a certain point.

\section{Geographical differences in the economic status of shamans}

From the above conclusion it would also follow that all Eskimos who underwent a shaman education rose from a low-status situation; that they remained low status persons within the dividion of labour by sex; but through their recognition as shamans they would obtain increased personal security in their low-status situation.-This conclusion, however, can only be made to hold good with any certainty for shamans in three Eskimo groups in Alaska: Nuniwagamiut, on the Island of Nunivak in the Bering Sea (South Alaska) (Lantis 1946); the whale hunting Eskimos at Point Barrow in North Alaska (Spencer 1959); and their neighbours to the South, Nunamiut, who were inland Eskimos with caribou hunting as their chief source of provision (ibid.).

Sources for other Eskimos in Alaska (and Siberia) do not yield sufficient information about the recruitment and economic status of shamans. The sources for Canada and Greenland, on the other hand, are more complete on these points, and in these two areas shamans with a high economic

\footnotetext{
${ }^{8}$ My evaluation is based on sources (and stories) from most Eskimo groups, e.g. Sandgreen 1967, I-II; Qúpersimân 1972; references to Western Greenland in Sonne, n.p.;
}

Balikci 1970; Spencer 1959; Lantis 1946; Nelson 1899; and Ray 1966.

9 The Eastern Greenlanders' synonym for spirit helpers (Sandgreen 1967 I-II). 
status were frequent. Similarly, in Canada and Greenland informal leaders who were at the same time shamans were not infrequent. But this combination was only a theoretical possibility in the three above-mentioned Alaskan groups, where in practice the shamans had a low economic status.

In the following I shall take three groups to represent respectively South Alaska: Nuniwagamiut; the whale hunting cultures of North Alaska: Taremiut at Point Barrow; and the Northernmost inland Eskimos of the same region: Nunamiut. This restriction is made for reasons of economy, and each mention implies my reservations as to their representativity for the three entire regions.

For reasons which will shape my final conclusion, the shaman's task was definitely more attractive in Canada and Greenland than it was in Alaska. This is seen not only in the different economic statuses of shamans in the West and in the East, but also by the way in which the shamans were recruited. In Alaska a person rarely became a shaman of his own free will. He was most often "called" through illness or acute psychotic seizures, a "call" which as a rule was unavoidable if the called person wanted to survive. In Canada and Greenland the "call" to be a shaman was a far rarer occurrence, and if it did occur the person struck could in some instances (Lynge 1955, 1967) himself decide whether he or she would follow the "call" or not. Most frequently a person would commence a shaman education on his own resolve, unless his parents had already taken this decision while he was still in the womb. In that case the parents executed certain rituals at his birth, which in later life were to make him attractive to the spirits: that is, the spirits would be attracted by his person and offer their service as his future helping spirits.

But why, then, was the shaman's task more attractive in Canada and Greenland than in Alaska? Why was shaman-and-leader status a more frequent combination in East than in West? As far as my analysis is concerned, the answer lies in two factors: 1 . The ritual position of the shaman, and 2. The degree of complexity in the leadership structure of society.

As regards 1, a table with corresponding graph shows the following facts: In Canada, Greenland, and among Nunamiut in North Alaska, these ritual tasks made up a far larger share in the aggregate ritual pattern, than among the whale-hunting Eskimos of North Alaska or among South Alaskan Eskimos. But the degree of complexity in leadership structure within the societies in question shows a slightly different distribution. To this latter point I shall return when I have commented upon the typology in the graph of collective rituals, and the tasks that the shaman executed within these.

The collective rituals of the Eskimos I have divided into four types. Type 
Table 1. Collective rituals and shaman participation among Eskimos Shaman participating +-

\begin{tabular}{|c|c|c|c|c|c|c|}
\hline & \multirow{2}{*}{\multicolumn{2}{|c|}{$\begin{array}{l}\text { Calender } \\
\text { rituals }\end{array}$}} & \multicolumn{3}{|c|}{ Situation rituals } & \multirow{2}{*}{$\begin{array}{l}\text { Show-off } \\
\text { séances }\end{array}$} \\
\hline & & & Expecta & able & Crisis & \\
\hline Siberia & Many & $+1-$ & & $?$ & + & $?$ \\
\hline N. Alaska & & & Few & - & + & \\
\hline Whaling & Few & $+1-$ & & & & Period? \\
\hline (Pt. Barrow) & Few & - & & & & Dec.-Jan. \\
\hline Nunamiut, caribou & & + & & & & Dec.-Jan. \\
\hline S. Alaska & Many & $+1-$ & Many & - & + & $\begin{array}{l}\text { Trad, rit. } \\
+ \text { other? }\end{array}$ \\
\hline Pacific coast & Few? & $?$ & Many & - & + & Period? \\
\hline Canada & & & $\mathrm{O} / \mathrm{Few}$ & - & + & $\begin{array}{l}\text { Winter } \\
\text { season }\end{array}$ \\
\hline S. E. Baffinland & 1 & + & & & & \\
\hline N. Labrador & 1 & + & & & & \\
\hline Iglulik & $1 ?$ & $(+)$ & & & & \\
\hline Rest of Canada & 0 & - & & & & \\
\hline Greenland & 0 & - & O/Few & - & + & $\begin{array}{l}\text { Winter } \\
\text { season }\end{array}$ \\
\hline
\end{tabular}

A are the Calendar Rituals, which were fixed by regularly recurring natural events in the annual cycle. Types $B$ and $C$ are jointly called Situation Rituals, since their occasion is an event that occurs in the life of the individual or of society, and so is without any fixed "date" within the annual cycle. Rituals of type B were celebrated for Expected Situations or events. Whether these befell single persons or the entire society, they would of course have to concern society as a whole to call forth the collective ritual. They might fall both in the life cycle of individuals (chief rites of passage) and in connection with seasonally fixed occupations under the latter sub-heading. Expected situation rituals as a rule immediately followed the event in question, although at times and in certain groups the event might be celebrated in two other ways: 1 . Both immediately and later in a calendar ceremony, where it formed only a link in a long sequence of rituals. 2. Not immediately but only later within a calendar ceremony. The rules that governed those three groupings of celebrations, would vary from society to society.

Rituals of the C-type could be called Unexpected Situation rituals, since the event that produced them was a non-expected occurrence, and it may best be characterized as a situation of crisis. 
Calender rituals

\section{$\times x$}

Expected situation rituals

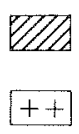

Show-off rituals

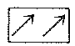

(Areas indicate approximate frequency)

North Alaska

Whaling

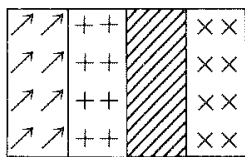

Northern Alaska

Nunamiut

Caribou-hunting

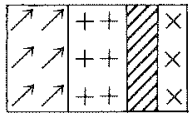

South Alaska

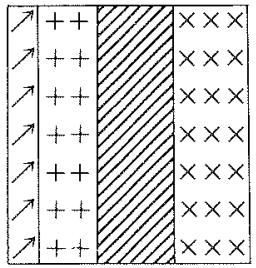

North-East Canada

Baffinlanders,

Labradorians

and lglulik

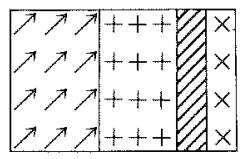

Rest of Canada and Greenland

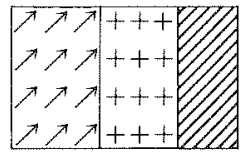

Occupation-organizing leadership

Occupation-organizing leadership

Leadership

Leadership

Exemplary leaders

Fig. 1. Graph of collective ritual types by frequency and territories.

The final type D is the Show-Off Ritual, a free shaman séance with no religious end in any direct sense. Their aims were twofold: firstly, the shamans gave clear proofs of their powers in order to further their own shaman prestige, and for their entourage to realize their powers and performance. Secondly, the show-off séances served as entertainment and enacted information about the ways of the world-odd and complicated yet understandable. In this way the function of these séances came to be a sort 
of object lesson, and a corroboration of the lore contained in the commonly held store of tales.

From the graph it will be seen that in Alaska, shamans' show-off rituals were limited to two months of the year, the dark winter months (Spencer, 1959).- It may be added about of these rituals on Nunivak, that they took place most frequently in connection with the ritualized trading festivals celebrated by two or more villages. They would host them in turn, so that over a couple of years the festivals as a rule became fixed annual events (Lantis 1946).-In Canada and Greenland these rituals, as shown in the graph, were not limited to the same extent as in Alaska to a brief span of time. They were spread throughout the whole winter season, and usually they took place on the shaman's own initiative, or in connection with visits from other settlements.

The shaman's ecstatic tasks in other rituals were distributed as follows across the entire Eskimo territory: the rituals of crisis were his speciality, but it was extremely rare for his expertise to be called for in the collective rituals for expected situations. And in the event that his society had a single or several calendar festivals, the shaman had ritual obligations in at least one calendar festival. (Point Barrow presents a single certain exception op. cit.). In North Alaska (and Siberia) the shaman's tasks were limited to a few minor ecstatic leavens in several calendar festivals, each in itself often considerable in extent. He had corresponding brief functions in the calendar festivals of South Alaska and of North-Eastern Canada, but in Canada he would also function as obligatory leader of ceremonies; and in South Alaska he could be requested to undertake that ceremonial task. In North Alaska the umialik or leader would always carry out such tasks.

\section{Digression on calendar rituals}

The exclusive occurrence of calendar ceremonies among most Western (=Alaskan+Siberian) Eskimos and North East Canadian Eskimos (Labrador, Baffinlanders and Iglulik) seems to depend on two social factors: 1. the longer duration of the sedentary period as compared to the nomadizing one, and 2. leaders who would organize and direct the common hunt on a contractual basis (see below p. 144). Thus the Baffinlanders, the Labrador, and to some extent the Iglulik Eskimos, formed settled winter-tospring communities of much longer duration than those of other Canadian Eskimos (Caribou, Netsilik, Copper). The first mentioned groups had an annual ceremony (not entirely certain for the Iglulik (Boas 1888, 669)), whereas the latter three did not.

The longer sedentary period cannot, however, account for the calendar ceremony among Nunamiut in North Alaska (Spencer 1959). They cohabit- 
ed in sedentary communities for only a couple of months twice in the annual cycle, to nomadize all the rest of the year. In contrast to the other Inland Eskimos in North Alaska and Canada, who celebrated no calendar rituals, the Nunamiut's common caribou hunt was directed by a contractual leader, the umialik. This leader both arranged the annual ceremony and paid the hired shamans for their services in the cult (ibid.). This contractual type of leadership may thus explain the calendar ceremony among the Nunamiut.

A third, and perhaps primary, factor underlying calendar rituals could be the sheer size of communities. Baffinland censuses from the 1880's to the 1920 's give the number of temporary Eskimo settlers around European whaling stations at 150 to 250 persons during the whaling season (Milleward 1930). For the same 50 years of intensive European whaling, we have descriptions of the Sedna cult celebrated at these stations. Whether the smaller Eskimo settlements actually celebrated the cult too, we are not directly told; but they formed a maximum of 50 persons (ibid.). The number of persons at settlements in pre-European days, with native whaling, is of course unknown. Archeology may provide a clue.

Sources then leave us with two documented factors: the longer sedentary period; and contractual leaders organizing hunt and celebrations.

\section{The ritual positions of shamans}

The graph (p. 141) shows the five patterns of ritual types in their proportional distribution. It indicates a distinct preponderance in Alaska of two types which called for the cooperation of the shaman's ecstatic abilities, to a limited extent only or not at all, viz. the calendar festivals and the expectedsituation rituals. - In Canada and Greenland and among the Nunamiut, two other types were dominant, the shaman's rituals of crisis and of show-off.

The whale-hunting cultures of North Alaska are the ones most fully described in this area. They are on an intermediate level both as regards number and distribution of the four ritual types. (Sources are few however for the smaller coastal cultures, so no patterning can be given for their rituals.)

To sum up: the shamans' ritual position, i.e. their relative parts in ritual patterns within the five areas, are not identical. Their parts were large in Canada, Greenland, and among the Nunamiut; less in the whale-hunting cultures of North Alaska; and negligible in South Alaska. ${ }^{10}$

We could then make the following assumption: the shaman's ritual position, high or low, will coincide with his high or low economic status. If

10 Marsh (1954) makes the same observation, although his interpretation in a setting of evolutionary theory would need further criticism, beyond the limits of this paper. 
so, the formula would run as follows: a proportionally large part in the ritual patterns should correspond to high economic status; and obversely, a small part in rituals would conform to a low status in economy. But this relationship is contradicted by the conditions among the Nunamiut: here the shaman's ritual participation was extensive, but his economic status was poor. Thus ritual position can not be the sole factor determining the shaman's economic status. But when we introduce a second factor, the degree of complexity in leadership structure, the jigsaw forms a neater picture.

\section{Leadership}

I select this factor from one of Lewis's conclusions above, viz: in societies with a well-developed organisation, shaman tasks and leadership are separate functions which cannot be united in the same person. But in societies without political organisation, this combination is possible.

Eskimo leadership may be roughly divided into four categories, taking the leader's authority and his responsibilities as criteria. In some societies, an organized cooperation under a single person's leadership was necessary for carrying out the chief occupations, as also for making war expeditions, which could be lucrative too). We find two categories of leadership in these societies: one is inheritable (Pacific Eskimos), the other is non-inheritable. In addition, this latter is no properly elected leadership, since a man would offer himself as economic leader and be accepted as such, without any elective process (North Alaskan whale-hunting cultures, and Nunamiut, with their organized collective hunting of whales and caribou).-In the remaining Eskimo societies, hunting as a rule was carried out on a more individual basis. But when at intervals coordination was necessary in collective hunts, the latter were led by a person who did not have the same authority and responsibility as the occupation-organizing leaders. These latter would contract with the single participants in a hunt, and their bond obliged the leader to take upon himself rather considerable economic obligations towards the participants. A similar bonding with built-in obligations is unknown in other Eskimo societies. The possible leader of a collective hunt and the other participants took part on identical economic conditions. ${ }^{11}$ Each participant, including the leader, had his share in the catch which he himself killed or had taken part in killing, in conformity with the rules in force concerning shares of catch.

11 In Western Greenland a collective hunt e.g. of caribou, was led by some acknowledged specialist, irrespective of his total economic status, which might be low. From the expedition's start till its end he was a leader, but neither before not after (Professor Robert Petersen, field notes, and personal communication). 
The leader in South Alaska (Bering Sea area) and in North Eastern Canada constitute the third type, with less formal obligations than the above two types. In S. Alaska he took the initiative in the ritualized trading festivals, and in N. E. Canada he watched the sharing of meat, which followed fairly complicated rules.

At this point we can return to the shaman's status in relation to two factors: his ritual position, and the complexity of leadership structure.

The highest complexity was found among the Pacific Eskimos with their inheritable and occupation-organizing leadership. And, if the isolated source for Kodiak in the Pacific is reliable, the combination of leader and shaman status in the same person was not even a theoretical possibility there (the Kodiak shaman, an unmarried transvestite and thus placed in the female line, as a matter of course could not inherit leadership status from a possible near male relative).

One step farther down in complexity, we find the leaders in the whalehunting cultures, and among the Nunamiut the leader organizing occupations and war. In those two cultures, the combination of leader and shaman status in the same person was theoretically possible, but in practice it was rarely or never realized. The shamans had a low economic status, in contrast to the high status of respected mature men. And in spite of the fact that the shaman among the Nunamiut had a high ritual position, this was obviously without importance within their relatively complex structure of leadership.

But when we compare Nunivak (South Alaska) and Northeast Canada, where the shaman's social position was respectively low and high, this difference cannot be explained by differences in the leadership structures, which can be placed at the same level on the last but one step in the complexity scale. On the other hand, differences in the shaman's ritual positions correlate neatly with differences in their economic status.

Finally, at the bottom of the scale, we find the exemplary leader. He was the leader type in the rest of Canada and in Greenland, where the shaman's economic status was often high, and his part in the ritual pattern equally considerable.

In other words: the task of shaman was more attractive in Canada and Greenland, because the shaman had a central place in the ritual pattern. Within this pattern it was mainly during the shaman's séances that the collective asserted their common religious ideas. In Alaska his task was less attractive; either because the shaman had only a small part in the ritual pattern; or because a relatively well-developed leadership had obviously tended to prevent the professional ecstatic from obtaining leadership status. 


\section{Conclusion}

The Eskimo data appear to confirm Lewis's first hypothesis: the more complicated the political organisation of a society, the greater the probability of the statuses of leader and of shaman never being united in the same person. But Lewis's view of the Eskimo shaman's potentiality for social control, via his supervision of the rules of taboo, has to be revised. The shaman exerted a certain control in his function as a witch-finder who was himself the object of social control. His further influence depended on a high economic status, and on positive traits of character, which might endow him with leadership status. But the more complex the type of leadership, the smaller were his obvious possibilities of obtaining this leader's status. With the type of leader becoming increasingly simple, this possibility would grow: always dependent on the centrality of the shaman's position within the ritual pattern.

This represents the limit of my hypotheses, which can also be tested against the social and ritual positions of professional ecstatics in various societies. In ethnographical literature, sociological criteria have often been employed in delimiting his status; whereas his part in ritual has not been the subject of similar interest and proper research in depth. That ritual position may provide an indication of the ecstatic's status has been demonstrated as the preliminary result of this analysis.

The next step in analysis must be as follows: taking the ritual position as an analytical tool, the social conditions that influence the socioreligious content and extent of ritual patterns can be clarified (as far as sources will allow). This analysis, however, must await another occasion.

\section{References}

Literature on Eskimos is categorised by regions:
(General)
all regions.
(S.)
(Pac.)
Siberia and St. Lawrence Island.
(S.A.)
Pacific: Southern coast of Alaska and the Aleuts.
(N.A.)
South Alaska: Bering Sea region.
(C.Can.)
North Alaska and Bering Strait Islands.
(N.E.Can.)
Central and North West Canada.
(N.G.)
(W.G.)
North Eastern Canada.
(E.G.)
Northern Greenland.
Western Grenland.
Eastern Greenland.

The Alaskan Eskimos. 1952. Ed. by H. Ostermann. (Report of the 5th Thule expedition 10,3.) Copenhagen. (N.A. + S.A.). 
Balikci, A. 1963. Shamanistic behaviour among the Netsilik Eskimos. South Western journal of anthropology 19.

- 1970. The Netsilik Eskimo. New York. (C. Can.).

- 1973. The Netsilik Eskimos: adaptive processes. Man the hunter, ed. by R. B. Lee and I. de Vore, Chicago. (C. Can.)

Bilby, J. W. 1923. Among unknown Eskimo. London. (N. E. Can.).

Birket-Smith, K. 1924. Meddelelser om Gronland 66. The ethnography of the Egedesminde district. Copenhagen (W. G.).

- 1929. The Caribou Eskimos. (Report of the 5th Thule expedition 5.) Copenhagen. (C. Can.).

- 1953. The Chugach Eskimo. (Nationalmuseets skrifter. Etnografisk række 6.) Copenhagen. (Pac.).

Black, L. I. (ed.) 1977. The Konyak (The inhabitants of the Island of Kodiak) by Iosaf (Bolotov) (1794-1799) and by Gideon (1804-1807). Arctic anthropology 14, 2. (Pac.).

Boas, F. 1888. The Central Eskimo. Sixth annual report of the Bureau of ethnology. Washington. (N.E.Can.).

- 1901-1907. The Eskimo of Baffin Land and Hudson Bay 1-2. Bulletin of the American museum of natural history 15. (N.E.Can.)

Bogoras, W. 1913. The Eskimo of Siberia. (The Jesup North Pacific expedition 8, 3.) New York. (S.).

Bourguignon, E. 1973. Religion, altered states of consciousness, and social change. Ohio.

Curtis, E. 1930. The North American Indian 20. New York/London. (S.A. + N.A.).

Dalager, L. 1915. Grønlandske Relationer ... 1752. (Det grønlandske Selskabs Skrifter 2.) København. (W.G.).

Damas, D. 1968. The Eskimo. Science, history and Hudson Bay, ed. by R. Beals 1. Ottawa. (C.Can. + N.E.Can.).

- 1973. The diversity of Eskimo societies. Man the hunter, ed. by R. B. Lee and I. de Vore. Chicago. (N.E.Can. + C.Can.).

Douglas, M. 1975. Naturlige symboler. København.

Egede, H. 1925. Omstcendelig og udførlig Relation ... og Grфnlands nye Perlustration og Naturel Historie.(Meddelelser om Grønland 54.) København. (W.G.).

- 1971. (Same, ed. Finn Gad). København.

- 1939. Contintation of Relationerne ... 1734-1740. (Meddelelser om Grønland 120.) København.

- 1971. (Same, ed. Finn Gad). København. (W.G.).

Fejes, C. 1966. Peoples of the Noatak. New York. (N.A.).

Giddinge, J. L. 1961. Kobuk River People. Univ. of Alaska. Studies of Northern Peoples 1. College. (N.A.).

Glahn, H. C. 1771. Anmarkninger over ... Crantzes Historie om Grønland. (W.G.).

- 1921. Dagb申ger for Aarene 1763-64, 1766-67, og 1767-68, ed. by H. Ostermann. (Det grønlandske Selskabs skrifter 4.) København. (W.G.).

Gubser, N. J. 1965. The Nunamiut Eskimos: Hunters of Caribou. New Haven/London. (N.A.).

Hawkes, E. W. 1913. The "Inviting-In" feast of the Alaskan Eskimo. Canada, Department of Mines, Geological Survey, Memoir 45: 3, Anthropological Series, Ottawa. (S.A.). 
- 1914. The dance festivals of the Alaskan Eskimos. Univ. of Pennsylvania, The Univ. Mus. Anthropological Publ, 6, 2. Philadelphia. (S.A. + N.A.).

- 1916. The Labrador Eskimo. Canada Geological Survey, Memoir 91: 14. Anthropological Series. Ottawa. (N.E.Can.).

Himmelheber, H. 1951. Der Gefrorene Pfad. Eisenach. (Kassel). (S.A.).

- 1953. Eskimokünstler. Eisenach. (Kassel). (S.A.).

- 1980. Ethnographische Notizen von den Nunivak-Eskimo. (Abhandlungen und Berichte des Staatlichen Museums für Völkerkunde. Forschungsstelle Dresden 38.) Berlin. (S.A.).

Hoebel, E. A. 1967. Song duels among the Eskimo. Law and Warfare, ed. by P. Bohannan, New York. (General).

Holm, G. 1888. Ethnologisk Skizze af Angmagssalikerne. (Meddelelser om Grønland 10.) København.

- 1911. Ethnological Sketch of the Angmagssalik Eskimo. (Meddelelser om Grønland 39,1.) Copenhagen. (E.G.).

Holm, G.-Petersen J. 1921. Angmagssalik distrikt. Grønland $i$ Tohundredeåret for Hans Egedes Landing. (Meddelelser om Gronland 61, 2.) Copenhagen. (E.G.).

Hrdlička, A. 1944. The Anthropology of Kodiak Island. Philadelphia. (Pac.).

Hughes, C. C. 1958. An Eskimo deviant from the "Eskimo" type of social organization. American anthropologist 60. (S.A. + S.).

- 1959. Translation of I. K. Voblov's Eskimo ceremonies. Anthropological Papers of the University of Alaska 7, 2. College. (S.).

Ingstad, H. 1954. Nunamiut. London. (N.A.).

Jacobsen, J. A. 1977. Alaskan Voyage 1881-1883. Chicago. (S.A. + N.A.).

Jenness, D. 1922. The life of the Copper Eskimos. (Report of the Canadian arctic expedition 1913-18 12.) Ottawa. (C. Can.).

- 1928. The people of the twilight. New York. (C.Can.).

Jochelson, W. 1933. History, ethnology and anthropology of the Aleut. Washington. (Pac.).

Keithan, E. L. 1976. Alaskan igloo tales. Anchorage. (N.A.).

Kleivan, I. 1971. Song duels in West Greenland. Folk 13. (W.G.).

Lantis, M. 1946. The social culture of the Nunivak Eskimo. Transactions of the American philosophical society. N.S. 35,3 Lancaster. (S.A.).

- 1947. Alaskan Eskimo ceremonialism. (Monographs of the American ethnological society 11.) Seattle/London. (S.A.).

- 1960. Eskimo childhood and interpersonal relationships. (The American ethnological society, Monograph 33.) Seattle/London. (S.A.).

Lewis, I. M. 1971. Ecstatic religion. Middlesex.

Lynge, H. 1955. Inegpait eller fornemme mennesker ... Upernavik Norddistrikts Aldre Historie. (Meddelelser om Grønland 90, 2.) (W.G.).

- 1967. Inugpat. Upernaviup ergâta oqalugtuagssartai. Godthăb. (W.G.).

Marsh, G. H. 1954. A comparative survey of Eskimo-Aleut-religion. Anthropological papers. Alaska University. (General).

Mathiassen, T. 1928. Material culture of the Iglulik Eskimos. (Report of the 5th Thule Expedition 6,1.) Copenhagen. (N.E.Can.).

Michael, H. N. (ed.). 1967. Lieutenant Zagoskin's Travels in Russian America, 1842-44. Arctic Institute of North America. Anthropology of the North: translations from Russian sources 7 . Toronto. (S.A.).

Milleward, A. E. 1930. Southern Baffinland. Department of the Interior North West Territories and Yukon Branch. Ottawa. (N.E.Can.). 
Moore, R.D. 1923. Social life of the Eskimo of St. Lawreme Island. American anthropologist, N.S. 25. Menasha. (S.).

Murdock, G. P. 1967. Ethnographic atlas. (U.S.A.).

Murphy, J. M. 1964. Psychotherapeutic aspects of shamanism on St. Lawrence Island, Alaska. Magic faith and healing, ed. by A. Kiev. London/New York. (S.).

Nelson, E. W. 1899. The Eskimo about the Bering Strait. (18th Annual Report of the Bureau of American ethnology 1.) Washington. (S.A. + N.A.).

Qúpersimân, G. 1972. taimane gâtimik nalussâgama. Godthåb. (E.G.).

Rainey, F. Q. 1947. The whale hunters of Tigara. (Anthropological papers of the American museum of natural history. 41, 2.) New York. (N.A.).

Rasmussen, K. 1905. Nye Mennesker. København. (N.G.).

- 1908. The people of the polar north. London. (N.G.).

- 1921. Myter og Sagn fra Gronland 1. Kjøbenhavn. (E.G.).

- 1929. Intellectual culture of the Iglulik Eskimos. (Report of the 5th Thule expedition 7, 1.) Copenhagen. (N.E.Can.).

- 1930. Observations on the intellectual culture of the Caribou Eskimos. (Report of the 5th Thule expedition 7.) Copenhagen. (C.Can.).

- 1931. The Netsilik Eskimos. (Report of the 5th Thule expedition 9.) Copenhagen. (C.Can.)

- 1932. Intellectual culture of the Copper Eskimos. (Report of the 5th Thule Expedition 9.) Copenhagen. (C.Can.).

- 1938. Knud Rasmussen's posthumous notes on the life and doings of the east Greenlanders in olden times. Ed. by H. Ostermann. (Meddelelser om Grønland 109, 1.) Copenhagen. (E.G.).

Ray, D. J. (ed.) 1966. The Eskimo of St. Michael and vicinity as related by H. M. V. Edmonds. Anthropological papers of the University of Alaska 12, 2. College. (S.A.).

Rink, H. 1974. Tales and traditions of the Eskimo. Copenhagen. (W.G.).

Rooth, A. B. 1971. The Alaska expedition 1966. (Acta Universitatis Lundensis. Sect. 1, 14.) Lund. (N.A.).

- 1960. Isimardik. (Det grønlandske selskabs skrifter 20.) København. (E.G.).

- 1963. Sagn og saga fra Angmagssalik. København. (E.G.).

- 1970. Kimilik. København. (E.G.).

Sandgreen, O. 1967. isse issimik kigutdlo kigúmik 1-2. Godthåb. (E.G.).

Sibisi, 1975. Spirit possession in Zulu cosmology. Religion and social change in southern Africa ed. by M. G. Whisson and Martin West.

Siikala, A. L. 1978. The rite technique of the Siberian shaman. (FF Communications 220.) Helsinki.

Sonne, B, 1978. Ritual bonds between the living and the dead in Yukon Eskimo society. Temenos 14. (General).

- Blodhavnens ideologi og virkelighed $i$ Vest- og Østgrфnland. (W.G./E.G.) Forthcoming in Etudes/Inuit/Studies.

Spencer, R. F. 1959. The North Alaskan Eskimo. (Bureau of American ethnology. Bulletin 171.) Washington. (N.A.).

Steenhoven, G. van den 1962. Leadership and law among the Eskimo of the Keewatin District. Northwest Territories. (C.Can.).

Steensby, H. P. 1910. Contributions to the ethnology and anthropology of the Polar Eskimos. (Meddelelser om Grønland 34.) Copenhagen. (N.G.).

Swantz, M.-L. 1976. Dynamics of the spirit possession phenomenon in Eastern 
Tanzania. Dynamics and institution, ed. by H. Biezais. (Scripta Instituti Donneriani Aboensis 9.) Uppsala.

Søby, R. M. 1969/70. The Eskimo animal cult. Folk 11-12. (General).

- 1977/78. The kinship terminology in Thule. Folk 19-20. (N.G.).

Saabye, H. E. 1816. Brudstykker af en Dagbog holden $i$ Gr $\phi$ nland. Odense. (W.G.). Thalbitzer, W. 1941. Social customs and mutual aid. The Ammassalik Eskimo 2. (Meddelelser om Grønland 40, 4.) Copenhagen. (E.G.).

Thornton, H. R. 1931. Among the Eskimos of Wales, Alaska 1890-93. London. (N.A.).

Turner, L. M. 1894. Ethnology of the Ungava District. I1th annual report of the Bureau of ethnology. Washington. (N.E.Can.).

Weyer, E. M. 1932. The Eskimos. Hamden. (General). 